\title{
POLITIK HUKUM PEMBERLAKUAN GELAR “SARJANA HUKUM” UNTUK ALUMNI JURUSAN HUKUM BISNIS SYARIAH
}

\author{
Mohamad Nur Yasin \\ Fakultas Syariah UIN Maulana Malik Ibrahim \\ Email: yasinm.nuryasin@yahoo.co.id
}

\section{Abstract}

The national education system implemented in Indonesia is within the positive legal frame. Its output quality must be measured legally by giving an academic degree. The degree of the Sharia Business Law (Muamalah) graduates is changed from Doctorandus/ Doctoranda (Drs/Dra), Sarjana Agama (S.Ag.), Sarjana Hukum Islam (SHI), Sarjana Syariah (S.Sy), into Sarjana Hukum (SH) today. The changes from SHI/S.Sy to SH contains legal politic meaning. This paper focuses on two problems (a) how the legal politic of the degree of $S H$ is, and (b) whether the degree of SH becomes an ideal solution for Sharia Business Law (Muamalab) graduates. By using normative law method, there are two findings. First, legal politic of the degree of $S H$ consist of $(a)$ the politic of legal formulation, namely the formulation of degree of SH which is done in top-down and bottom-up, (b) the law substance strengthens the integration of knowledge and institution, and (c) the politic of legal enactment shows that there are contra-justisia and miss-understanding under perspective of magister program of law management and stakeholders to Sharia Business Law (Muamalab) graduates. Second, the admissibility of the graduates in law sector should not automatically in tandem with the degree of $S H$.

Sistem pendidikan nasional dilaksanakan di Indonesia dalam bingkai bukum positif. Kualitas out put pendidikan harus diukur secara hukum dengan pemberian gelar akademik. Gelar akademik yang disandang oleh lulusan Jurusan Hukum Bisnis Syariah (Muamalab) mengalami perubahan mulai dari Doctorandus/ Doctoranda (Drs/Dra), Sarjana Agama (S.Ag.), Sarjana Hukum Islam (SHI), Sarjana Syariah (S.Sy), dan Sarjana Hukum (SH). Perubahan gelar akademik 
dari SHI/S.Sy menjadi SH mengandung makna politik bukum. Tulisan ini fokus pada dua permasalahan, yaitu (a) bagaimana politik bukum gelar SH dan (b) apakah gelar SH menjadi solusi ideal bagi lulusan Jurusan Hukum Bisnis Syariah (Muamalah). Dengan menggunakan kajian bukum normatif diperoleh dua temuan. Pertama, politik hukum gelar SH terdiri atas (a) politik perumusan bukum, yakni perumusan gelar SH dilakukan secara top down and buttom up, (b) politik substansi hukum, berupa penguatan semangat integrasi keilmuan dan kelembagaan, dan (c) politik pemberlakuan hukum, bahwa ada pertentangan bukum dan kesalahpahaman dalam pandangan pengelola program magister ilmu bukum dan stakeholders bukum terhadap lulusan Jurusan Hukum Bisnis Syariah (Muamalah). Kedua, keterserapan lulusan Jurusan Hukum Bisnis Syariah (Muamalah) di sektor hukum tidak otomatis terjamin dengan berlakunya gelar SH.

Keywords: sharia business law, degree of $\mathrm{SH}$, fresh graduate, legal politic

\section{Pendahuluan}

Kewenangan untuk merumuskan visi dan mengelola alam raya sepadan dengan kesiapan diri manusia untuk mempertanggungjawabkan amanah kekhalifahan yang diembannya di muka bumi. ${ }^{1}$ Dalam konteks ketatanegaraan Indonesia modern, amanah kekhalifahan terwujud dalam bentuk Negara Kesatuan Republik Indonesia (NKRI). Pada alinea IV pembukaan Undang-Undang Dasar 1945 dinyatakan bahwa tujuan didirikannya NKRI adalah untuk melindungi segenap bangsa Indonesia dan seluruh tumpah darah Indonesia, memajukan kesejahteraan umum, mencerdaskan kehidupan bangsa, dan ikut melaksanakan ketertiban dunia yang berdasarkan kemerdekaan, perdamaian abadi serta keadilan sosial. ${ }^{2}$ Pemerintah Republik Indonesia sebagai pemegang kekuasaan eksekutif (executive power) melakukan upaya mencerdaskan kehidupan bangsa dengan cara menyelenggarakan sistem pendidikan nasional yang meningkatkan keimanan dan ketakwaan kepada Allah SWT serta akhlak mulia yang diatur dengan undang-undang. Sistem pendidikan nasional diobsesikan mampu menjamin pemerataan kesempatan pendidikan, peningkatan mutu dan relevansi serta efisiensi manajemen pendidikan untuk menghadapi tantangan sesuai dengan tuntutan perubahan kehidupan lokal, nasional, dan global. ${ }^{3}$ Sistem pendidikan nasional adalah keseluruhan komponen pendidikan yang terkait secara terpadu untuk mencapai tujuan pendidikan nasional. ${ }^{4}$ Sistem pendidikan nasional yang dilaksanakan di Indonesia terbingkai

1 QS, Al-Isra (17) ayat 36

2 Alinea 4 Pembukaan Undang-Undang Dasar Negara Republik Indonesia 1945

3 Konsideran Undang-Undang Nomor 20 Tahun 2003 Tentang Sistem Pendidikan Nasional

4 Pasal 1 poin (3) Undang-Undang Nomor 20 Tahun 2003 Tentang Sistem Pendidikan 
dalam wadah bangunan hukum nasional (national law building).

Hukum nasional yang berlaku di Indonesia adalah hukum positif. Hukum positif merupakan hukum tertulis yang berlaku di wilayah tertentu pada waktu tertentu. ${ }^{5}$ Disebut positif karena selain merupakan perintah penguasa juga memiliki tiga karakter, yaitu dapat diamati (observable), dapat diukur (measurable), dan dapat dibuktikan (verifiable). ${ }^{6}$ Pertama, observable. Setiap warganegara Indonesia yang dinyatakan benar atau salah harus bisa diobservasi (dilakukan penyelidikan dan penyidikan) untuk mengetahui apakah statusnya bebas, terlapor, tersangka, terdakwa, terpidana, atau tereksekusi. Kedua, measurable, yakni bisa diukur. Seseorang disebut bersalah atau tidak bisa diukur seberapa besar kesalahannya. Standar kebenaran dan kesalahan tercantum dalam peraturan perundang-undangan. Sebagai contoh(1) jika seseorang divonis denda, harus bisa diukur berapa juta atau milyard dendanya, (2) jika divonis penjara, harus bisa diukur berapa bulan atau tahun lamanya, jika divonis mati, bisa diukur kapan dilaksanakan. Ketiga, verifiable. Seseorang disebut benar atau salah bisa dibuktikan dengan berbagai barang bukti (BB), meliputi keterangan ahli, alat bukti, saksi, pengakuan, dan sumpah. Menurut Amiruddin dan Zainal Asikin, hukum positif adalah hukum yang berpegang pada pirnsip law as it is written in the book. Artinya, hukum adalah segala ketentuan yang tertulis dalam peraturan perundangan-undangan. ${ }^{7}$ Dengan demikian, nilai, prinsip, dan segala ketentuan yang belum tertulis di dalam peraturan perundangan-undangan belum bisa disebut hukum nasional Indonesia, tetapi merupakan bahan hukum nasional.

Proses pendidikan di Indonesia yang terbingkai hukum positif harus bisa diukur aspek perencanaan, proses, dan out putnya. Bentuk hukum pengukuran out put pendidikan tinggi di Indonesia adalah pemberian gelar akademik kepada mahasiswa yang telah berhasil menyelesaikan studi strata satu (S1), strata dua (S2), atau strata tiga (S3). Dengan menyandang gelar akademik seorang sarjana bisa diketahui telah mengikuti, mengkaji, dan mendalami proses pendidikan tinggi di bidang ilmu yang direpresentasikan oleh gelar akademiknya. Menurut Peraturan

Nasional

5 Brian Leiter,"Why Legal Positivism”?Public Law and Legal Theory, University of Chicago Law School Chicago Unbound, 2009. http://chicagounbound.uchicago.edu/cgi/viewcontent. cgi ?article $=13868$ context $=$ public_law_and_legal_theory, pdf, diakses 2 Desember 2016 . Lihat juga,Yudha Bhakti, Telaah Hukum Positif, , diakses 2 Desember 2016

6 HM. Atho Mudzhar, Pendekatan Studi Islam dalam Teori dan Praktek (Yogyakarta: Pustaka Pelajar, 1998), h. 13

7 Amiruddin dan Zainal Asikin, Pengantar Metode Penelitian Hukum (Bandung: Citra Aditya Bakti, 2006), h. 118. 
Menteri Agama(PMA) Nomor 33 Tahun 2006 Tentang Gelar Akademik Perguruan Tinggi Keagamaan, gelar akademik adalah gelar yang diberikan kepada lulusan pendidikan akademik bidang studi tertentu dari suatu perguruan tinggi yang terdiri atas sarjana, magister, dan doktor. ${ }^{8}$ Gelar akademik bersifat akomodatif dan responsif terhadap perkembangan ilmu. ${ }^{9}$ Gelar akademik diberikan kepada mahasiswa yang telah menyelesaikan semua persyaratan yang dibebankan dalam mengikuti suatu program studi dan dinyatakan lulus sesuai dengan ketentuan peraturan perundang-undangan. ${ }^{10}$

Gelar akademik berupa Sarjana Hukum Islam (SHI) atau Sarjana Syariah (S.Sy) menunjukkan bahwa seseorang yang menyandang gelar tersebut telah menyelesaikan pendidikan di Jurusan Hukum Bisnis Syariah (Muamalah) serta jurusan lain di Fakultas Syariah. Begitu juga dengan gelar yang lain menunjukkan keilmuan yang digelutinya, seperti Sarjana Ekonomi Islam (SEI) untuk alumni Jurusan Ekonomi Islam, Sarjana Pendidikan Islam (S.Pd.I) untuk alumni Fakutas Tarbiyah, Sarjana Ekonomi (SE) untuk alumni Fakultas Ekonomi, Sarjana Psikologi (S.Psi) untuk alumni Fakultas Psikologi, Sarjana Humaniora (S.Hum) untuk alumni Fakultas Humaniora dan Budaya, Sarjana Sains (SS) untuk alumni Fakultas Matematika dan Ilmu Pengetahuan Alama (MIPA), Sarjana Komunikasi (S.Kom) untuk alumni Teknik Informatika, Sarjana Teknik (ST) untuk alumni Fakultas Teknik, Sarjana Kedokteran (S.Ked) untuk alumni Kedokteran, Sarjana Farmasi (S.Farm) untuk alumni Farmasi, dan sebagainya. Di antara berbagai gelar akademik yang ada, gelar yang disandang alumni Jurusan HBS (Muamalah) Fakutas Syariah paling sering mengalami perubahan dalam perjalanan panjang sejarahnya. Diawali dengan Doctorandus/Doctoranda (Drs/Dra), ${ }^{11}$ Sarjana Agama (S.Ag), ${ }^{12}$

8 Pasal 1 poin (1) PMA No 33 Th 2016 Tentang Tentang Gelar Akademik Peguruan Tinggi Keagamaan

9 Pasal 2 ayat (1) PMA No 33 Th 2016 Tentang Tentang Gelar Akademik Peguruan Tinggi Keagamaan

10 Pasal 2 ayat (2) PMA No 33 Th 2016 Tentang Tentang Gelar Akademik Peguruan Tinggi Keagamaan

11 Aturan Peralihan Pasal II Undang-Undang Dasar Republik Indonesia 1945 (UUD 1945). Aturan Peralihan Pasal II UUD 1945 berbunyi "Segala badan Negara dan peraturan yang ada masih langsung berlaku selama belum diadakan yang baru menurut Undang-Undang Dasar ini”. Di antara peraturan yang ada masih langsung berlaku adalah penggunaan gelar akademik Doctorandus (Drs) dan Doctoranda (Dra) yang diberlakukan di Indonesia sejak zaman kolonial Belanda (sebelum kemerdekaan Indonesia, 17 Agustus 1945).

12 Keputusan Menteri Pendidikan dan Kebudayaan Republik Indonesia Nomor 036/U/1993 Tentang Gelar dan Sebutan Lulusan Perguruan Tinggi 
Sarjana Hukum Islam (SHI), ${ }^{13}$ Sarjana Syariah (S.Sy), ${ }^{14}$ dan mulai 9 Agustus 2016 berganti menjadi Sarjana Hukum (SH). ${ }^{15}$ Perubahan gelar dari SHI/S.Sy menjadi SH memiliki makna yang dalam perspektif politik hukum dapat dipetakan ke dalam politik perumusan hukum (legal formulation politic), politik substansi hukum, dan politik pemberlakuan hukum (enactment policy).

Politik hukum pemberlakuan gelar akademik dari SHI/S.Sy menjadi SH untuk alumni Jurusan HBS (Muamalah) Fakultas Syariah tidak lepas dari pengaruh dunia pasar kerja dan profesi berbasis hukum, yaitu jaksa, hakim, panitera, notaris, dan advokat. Syarat kesarjanaan untuk bisa mengikuti rekrutmen berbagai profesi hukum tersebut diatur dalam beberapa peraturan perundang-undangan. Pertama, menurut Pasal 9 ayat (1) UU No 16 Th 2004 Tentang Kejaksaan Republik Indonesia, syarat untuk menjadi jaksa adalah sarjana hukum. Kedua, syarat kesarjanaan menjadi hakim dan panitera pada peradilan umum adalah sarjana hukum. Hal ini tertuang dalam pasal 14 ayat (1) poin (f) dan pasal 29 poin (b) UU Nomor 2 Tahun 1986 tentang Peradilan Umum yang telah disempurnakan dengan UU Nomor 49 Tahun 2009 tentang Kekuasaan Kehakiman. Ketiga, dinyatakan dalam Pasal 3 poin (e) UU Nomor 30 Tahun 2004 Tentang Jabatan Notaris yang telah disempurnakan dengan UU Nomor 2 Tahun 2014 Tentang Perubahan Atas Undang-Undang Nomor 30 Tahun 2004 Tentang Jabatan Notaris, bahwa syarat untuk dapat diangkat menjadi notaris harus berijazah sarjana hukum dan lulusan jenjang strata dua kenotariatan. Keempat, menurut Pasal 2 ayat (1) UU Nomor 18 Tahun 2003 Tentang Advokat, bahwa yang dapat diangkat sebagai advokat adalah sarjana yang berlatar belakang pendidikan tinggi hukum dan setelah mengikuti pendidikan khusus profesi Advokat yang dilaksanakan oleh Organisasi Advokat. Makna kata "sarjana yang berlatar belakang pendidikan tinggi hukum" bisa dicermati pada penjelasan UU Pasal 2 ayat (1) UU Nomor 18 Tahun 2003 Tentang Advokat. Di dalam penjelasan tersebut dinyatakan, bahwa yang dimaksud dengan "berlatar belakang pendidikan tinggi hukum" adalah lulusan fakultas hukum, fakultas syariah, perguruan tinggi hukum militer, dan perguruan tinggi ilmu kepolisian.

13 Keputusan Direktur Jenderal Kelembagaan Agama Islam Departemen Agama Republik Indonesia Nomor: E/ 10/ Tahun 2002 Tentang Gelar dan Sebutan Lulusan Perguruan Tinggi Agama Islam.

14 Peraturan Menteri Agama Nomor 36 Tahun 2009 Tentang Penetapan Pembidangan Ilmu dan Gelar Akademik di Lingkungan Peguruan Tinggi Agama

15 Peraturan Menteri Agama Nomor 33 Tahun 2016 Tentang Tentang Gelar Akademik Peguruan Tinggi Keagamaan 
Pada perspektif kajian hukum normatif dapat dinyatakan bahwa dalam uraian di atas terdapat isu hukum berupa inkonsistensi hukum (inconsistention of norm) dan pertentangan hukum (conflict of norm) dalam norma rekrutmen calon penegak hukum di Indonesia. Inconsistention of norm tercermin dari tidak adanya penjelasan tentang cakupan dan makna "sarjana hukum" dalam UU Kejaksaan, UU Peradilan Umum, dan UU Jabatan Notaris di satu sisi. Sedangkan di sisi lain, terdapat penjelasan yang konkrit dan detail tentang cakupan dan makna "sarjana yang berlatar belakang pendidikan tinggi hukum" dalam UU Advokat. Adapun conflict of norm tergambar dari tidak adanya pengakomodasian dan penyerapan terhadap potensi alumni Jurusan Hukum Bisnis Syariah (Muamalah) Fakultas Syariah oleh UU Kejaksaan, UU Peradilan Umum, dan UU Jabatan Notaris, padahal UU Advokat dengan tegas mengakomodasi dan menyerap potensi alumni Jurusan HBS (Muamalah) Fakultas Syariah. Inconsistention of norm dan conflict of norm ini memunculkan ketidakpastian hukum di tengah masyarakat khususnya di kalangan alumni Jurusan HBS (Muamalah) Fakultas Syariah se-Indonesia. Meskipun alumni Jurusan HBS (Muamalah) Fakultas Syariah sudah mempelajari hukum Islam dan hukum umum, keberadaan mereka belum terakomodasi secara maksimal ke dalam substansi hukum nasional yang mengatur rekrutmen jaksa, hakim dan panitera peradilan umum, serta notaris.

Adanya inconsistention of norm dan conflict of norm dalam norma rekrutmen penegak hukum yang kemudian memunculkan ketidakpastian hukum di tengah masyarakat ini tidak searah dengan semangat keadilan. Tidak adanya keadilan dan tidak adanya pengakomodasian terhadap realitas lokal, dalam konteks ini direpresentasikan oleh eksistensi alumni Jurusan HBS (Muamalah) Fakultas Syariah, yang telah lama hidup dan tumbuh di tengah masyarakat ke dalam peraturan perundang-undangan negara (UU Kejaksaan, UU Peradilan Umum, dan UU Notaris) bisa dikategorikan serumpun dengan fenomena yang oleh Ann Elizabeth Mayer disebut sebagai problem dasar pengakomodasian hukum. Menurut Ann Elizabeth Mayer, problem dasar pengkodifikasian hukum Islam di negara Islam adalah munculnya konflik antara sumber hukum yang hidup dan mengakar di tengah masyarakat dengan hasil kodifikasi hukum Islam yang diundangkan di negara tersebut. Problem dasar yang sering muncul adalah tidak terakomodasinya praktek yang telah mengakar di masyarakat ke dalam kodifikasi hukum nasional. ${ }^{16}$ Peraturan perundangan yang sama sekali bertentangan dengan kebiasaan-kebiasaan masyarakat dan tidak didukung oleh lembaga pendapat umum yang berpengaruh,

16 Ann Elizabeth Mayer, "The Syariah: a Methodology or a Body of Substantive Rules", in Nicholas Heer, Islamic Law and Jurisprudence (Seattle and London: University of Washington Press, 1990), h. 198 
akan tetap tidak efektif. ${ }^{17}$ Namun di sisi lain, ketika Islam, terutama hukum Islam, bersinggungan dengan budaya suatu masyarakat akan terjadi proses dialogis kultural yang rumit. Dalam situasi yang demikian, Islam mengalami perubahan secara berkelanjutanpada tataran tradisi atau pranata keyakinan keagamaan. Sedangkan teks al-Quran dan doktrin normatif yang fundamental dari Islam tetap mapan. ${ }^{18}$

Tulisan ini mengkaji dimensi politik hukum pemberlakuan gelar akademik SH bagi alumni Jurusan HBS (Muamalah) Fakultas Syariah dan relevansinya dengan teori keadilan. Ada tiga pertanyaan yang penting untuk dikemukakan. Pertama, bagaimana politik hukum yang mengitari pemberlakuan gelar SH. Kedua, apakah pergantian gelar dari SHI/S.Sy menjadi SH bisa menjamin keterserapan di dunia pasar kerja bagi alumni Jurusan HBS (Muamalah) Fakultas Syariah.

\section{Metode Penelitian}

Jenis penelitian yang digunakan adalah yuridis normatif dengan pendekatan peraturan perundang-undangan. Bahan hukum terdiri dari bahan hukum primer yang meliputi Undang-Undang No.20 Tahun 2003 Tentang sistem pendidikan nasional, Undang-Undang No.16 Tahun 2004 Tentang Kejaksaan RI. UndangUndang No.28 Tahun 2003 Tentang Advokat dan peraturan perundang-undangan yang terkait, dan bahan hukum sekunder meliputi buku, hasil penelitian, dan catatan wawancara. Selanjutnya bahan hukum akan dianalisis secara yuridis kualitatif melalui teori keadilan.

\section{Pembahasan}

\section{Politik Hukum Pemberlakuan Gelar Sarjana Hukum}

Ada tiga cakupan politik hukum, yaitu perumusan hukum, substansi hukum, dan pemberlakuan hukum. ${ }^{19}$ Cakupan politik hukum juga mengiringi pemberlakuan gelar akademik "SH" untuk alumni Jurusan HBS (Muamalah) Fakultas Syariah.

17 James Norman Darlymple Anderson, Islamic Law in the Modern Word (Virginia: Greenwood Publishing Group, 1975), h. 97

18 Roland Robertson (ed), Agama dalam Analisa dan Interpretasi Saosiologis (Jakarta: Rajawali Press, 1988), h. Xii

19 Moh.Mahfud, Membangun Politik Hukum, Menegakkan Konstitusi, cet ke-3 (Jakarta: Rajawali Press, 2012), h. 14. Lihat juga, Mohamad Nur Yasin, "The Pluralism of Islamic Economic Law, Dialectic of Moslem and non-Moslem in the Development of Sharia Banking in Indonesia", Journal of Indonesian Islam, Vol. 10, Number 01, June 2016, 123 


\section{Politik Perumusan Hukum}

Politik perumusan hukum merupakan bagian dari mekanisme pembuatan hukum oleh DPR (rechtvoorming) atau pembuatan peraturan oleh lembaga yang memperoleh wewenang dari undang-undang. Menurut Sadjipto Rahardjo, sebuah produk hukum yang efektif selalu disangga oleh tiga pilar yaitu pilar filosofis (singkron dengan nilai tertinggi), pilar yuridis (singkron dengan peraturan di atasnya), dan pilar sosiologis (akomodatif terhadap nilai-nilaisosial kontekstual). ${ }^{20}$

Perumusan hukum untuk mewujudkan gelar akademik SH bagi alumni Jurusan HBS (Muamalah) Fakultas Syariah berlangsung lama dan melelahkan. Setidaknya ada tiga pihak yang konsen terhadap gelar SH untuk alumni Jurusan HBS (Muamalah) Fakultas Syariah. Pertama, berbagai kajian diselenggarakan oleh jajaran Direktorat Pendidikan Tinggi Islam Kementerian Agama Republik Indonesia di Jakarta. Kedua, usulan gelar SH sering muncul dari kalangan praktisi baik hakim dan panitera di lingkungan Peradilan Agama maupun para pengacara yang tergabung dalam Asosiasi Pengacara Syariah Indonesia (APSI). Ketiga, pembahasan paling intensif dan berkelanjutan tentang perubahan gelar akademik dari SHI/S.Sy menjadi SH dilaksanakan oleh forum Dekan Fakultas Syariah se-Indonesia.

Pembahasan perlunya gelar SH di forum Dekan Fakultas Syariah muncul pertama kali pada pertemuan Forum Dekan Fakultas Syariah di IAIN Antasari Banjarmasin tahun 2005. Ketika itu respon dari para Dekan Fakultas Syariah masih beragam. Secara umum pendapat yang berkembang terpola ke dalam dua kutub pemikiran. Pemikiran pertama tidak setuju gelar SH bagi alumni Fakultas Syariah dan memilih untuk mempertahankan gelar SHI. Pemikiran pertama ini dimotori Dekan Fakultas Syariah UIN Syarif Hidayatullah Jakarta, Prof. Dr. H. Muhammad Amin Summa, SH., MA. Sedangkan pemikiran kedua dimotori Dekan Fakultas Syariah UIN Malang periode 2005-2009, Dr. H. Dahlan Tamrin, M.Ag. Kelompok kedua setuju dengan gelar SH bagi alumni Jurusan HBS (Muamalah) dan jurusan lain di lingkungan Fakultas Syariah. ${ }^{21}$

Dalam rentang waktu 9 tahun (2005-2014) pembahasan gelar SH belum menunjukkan ada tanda-tanda kesepakatan di antara Dekan Fakultas Syariah. Hal ini antara lain disebabkan oleh situasi sosial ekonomi yuridis dan politik Indonesia yang relatif belum memerlukan perubahan gelar bagi alumni Fakultas Syariah. Dalam beberapa kali pertemuan berikutnya gagasan gelar $\mathrm{SH}$ selalu

20 Satjipto Rahardjo, Ilmu Hukum (Bandung: Citra Aditya Bhakti, 1991), h. 178

21 Catatan Observasi 2005. Ketika itu penulis menjadi utusan Fakultas Syariah IAIN Mataram dan merupakan salah satu peserta yang ikut hadir pada pertemuan di IAIN Antasari Banjarmasin 2015. 
dibahas, tetapi selalu belum menghasilkan rumusan yang bisa disepakati untuk meyakinkan pemegang kebijakan di Kementerian Agama Jakarta. Ketika forum Dekan Fakultas Syariah seluruh Indonesia periode 2013-2016 dipimpin oleh Dr. H. Roibin (Dekan Fakultas Syariah UIN Maulana Malik Ibrahim Malang) pembahasan gelar SH diintensifkan. Sampai akhirnya pada pertemuan forum Dekan Fakultas Syariah di UIN Maulana Malik Ibrahim Malang, Rabu, 22 Oktober 2014gagasan tentang gelar SH mengerucut, matang, dan akhirnya disepakati seluruh Dekan Fakultas Syariah yang kemudian dituangkan sebagai kritik dan rekomendasi yang dikirimkan ke pihak terkait.

Menurut rekomendasi forum Dekan Syariahdan Asosiasi Dosen Syariah Indonesia, penetapan pembidangan ilmu dan gelar akademik di lingkungan Perguruan Tinggi Agama, baik negeri maupun swasta yang tertuang dalam Peraturan Menteri Agama (PMA) Republik Indonesia Nomor 36 Tahun 2009 tidak menguntungkan Fakultas Syariah dan alumni mahasiswa Fakultas Syariah. Ada beberapa sebab tentang hal ini. Pertama, gelar Sarjana Hukum Islam (SHI) yang mulai direspon dan dikenal masyarakat pengguna lulusan diganti dengan gelar Sarjana Syariah (S.Sy) yang belum dikenali sama sekali oleh masyarakat pengguna lulusan. Gelar S.Sy menunjukkan istilah yang semakin abstrak di tengah masyarakat. Kedua, gelar SHI lebih dapat diterima untuk melanjutkan studi S2 di Fakultas Hukum dibanding gelar S.Sy. Ketiga, gelar S.Sy kurang menunjukkan kompetensi spesifik di bidang disiplin keilmuan hukum, mengingat ontologi Fakultas Syariah mengandung makna yang sangat luastidak terbatas pada permasalahan hukum,melainkan juga masalahaqidah dan akhlak. Keempat, untuk mensosialisasikan gelar baru yang abstrak membutuhkan waktu dan tenaga yang tidak sederhana. Mengacu pada empat pemikiran di atas cepat atau lambat PMA RI No 36 Tahun 2009 tentang pembidangan ilmu dan gelar akademik potensial berdampak secara langsung terhadap menurunnya daya saing mahasiswa Fakultas Syariah baik dalam skala lokal, nasional, maupun internasional. ${ }^{22}$

Salah satu alasan penting dari pembidangan ilmu dan gelar akademik adalah untuk mengakomodasi berbagai kompetensi keilmuan di lingkungan Perguruan Tinggi Agama. Namun, pada sisi lain pengambilan keputusan tersebut terkesan sangat normatif dan kurang berpijak pada pertimbangan empiris.Di antara kelemahan mendasar pembidangan ilmu dan gelar akademik yang tertuang dalam PMA RI No 36 Tahun 2009 adalah kurangnya nilairelevansional antara muatan keilmuan yang

22 Hasil Rekomendasi Pertemuan Forum Dekan/ Jurusan SyariahDan Forum Asosiasi Dosen Syariah IndonesiaDi UIN Maulana Malik Ibrahim Malang, Rabu, 22 Oktober 2014, syariah. uin-malang.ac.id//Hasil-Rekomendasi-Pertemuan-Forum-Dekan Syariah, diakses 27 Novemver 2016. 
dikembangkan di masing-masing perguruan tinggi dengan pemberian gelar yang tidak marketable. Hal ini tanpa terasa telah mengurangi reputasi dan kewibawaan sistem pendidikan di Perguruan Tinggi Islam terutama institusi Kementerian Agama RI. Keresahan ini semakin tampak di mata masyarakat akademik ketika prospek dan peluang kerja alumni Fakultas Syariah kurang dipertimbangkan kaitannya dalam pengambilan keputusan penetapan gelar tersebut. ${ }^{23}$

Perubahan pembidangan keilmuan dan gelar akademik dalam konteks sejarah telah terjadi. Dimulai dari gelar Drs/Dra menjadi S.Ag. Pada saat itu situasi kampus masih berstatus IAIN dengan tujuan kompetensi dan jelas arahnya serta berbagai alasan yang diberikan. Selanjutnya terjadi alih status dari IAIN menjadi UIN dengan memberikan peluang kompetensi yang lebih luas.Sehingga, gelar kesarjanaan dari Sarjana Agama (S.Ag) menjadi sarjana-sarjana yang sesuai dengan masing-masing bidang, seperti Sarjana Hukum Islam (SHI) dan Sarjana Ekonomi Islam (SEI). Perubahan itu potensial memberikan ruang dan peluang bagi setiap disiplin keilmuan yang ada di dalamnya. Termasuk pemberian gelar Sarjana Syariah dengan sebutan Sarjana Hukum Islam (SHI) perlahan tetapi pasti telah membuka peluang dan ruang yang cukup marketable. ${ }^{24}$

Sangat disayangkan jika sekarang muncul perubahan dan pembaruan peraturan baru yang kurang menangkap ruh dan esensi perubahan. Idealnya, semua perubahan tetap merenungkan esensi nilai kemaslahatan dan bukan perubahan yang tidak bermakna apalagi menutup peluang dan ruang gerak nasib anak bangsa. Dalam proses perubahan dan penetapan PMA No 36 Tahun 2009 ada empat permasalahan utama yang perlu dipahami. Pertama, adanya dikotomi keilmuan dengan ruang lingkup yang dipersempit, yaitu S.Sy terkesan diarahkan pada wilayah kompetensi "agama" an sich. Sedangkan SHI selama ini telah menepis praktik dikotomi keilmuan. SHI telah mampu mengintegrasikan kompetensi keilmuan hukum Islam dengan hukum positif. Kedua penetapan gelar tersebut merupakan keputusan sepihak yang kurang melibatkan pertimbangan forum Dekan Syariah seluruh Indonesia dan forum Asosiasi Dosen Syariah Indonesia yang telah merekomendasikan perubahan gelar dari SHI menjadi $\mathrm{SH} .{ }^{25}$

23 Hasil Rekomendasi Pertemuan Forum Dekan.syariah.uin-malang.ac.id//Hasil-RekomendasiPertemuan-Forum-Dekan Syariah, diakses 27 Novemver 2016.

24 Hasil Rekomendasi Pertemuan Forum Dekan.syariah.uin-malang.ac.id//Hasil-RekomendasiPertemuan-Forum-Dekan Syariah, diakses 27 Novemver 2016

25 Hasil Rekomendasi Pertemuan Forum Dekan.syariah.uin-malang.ac.id//Hasil-RekomendasiPertemuan-Forum-Dekan Syariah, diakses 27 Novemver 2016 


\section{Politik Substansi Hukum}

Politik substansi hukum merupakan arahan atau garis resmi di bidang hukum yang dijadikan dasar pijak dalam rangka mencapai tujuan bangsa dan negara. ${ }^{26}$ Politik substansi hukum berarti menjadikan produk hukum atau materi peraturan perundang-undangan sebagai objek politik, materi mana yang harus diakomodasi dan mana yang harus dieliminasi. Terkait dengan gelar akademik "SH" bagi alumni Jurusan HEBS (Muamalah) Fakultas Syariah, politik substansi hukum bisa dicermati dari konsideran pertama PMA Nomor 33 tahun 2016. Konsideran tersebut berbunyi "adanya perkembangan lembaga dalam perguruan tinggi keagamaan, perlu pengintegrasian bidang-bidang keilmuan dan pengaturan mengenai gelar akademik". Semangat yang menjiwai substansi hukum pada PMA No 33 Tahun 2016 adalah semangat integrasi, baik integrasi intelektual maupun integrasi institusional. Politik substansi hukum berupa integrasi keilmuan dan integrasi institusional di dalam gelar $\mathrm{SH}$ ini memiliki semangat yang sama dengan trend dan arah pengembangan keilmuan integratif di lingkungan Perguruan Tinggi Keagamaan Islam Negeri (PTKIN). Dengan semakin banyaknya PTKIN berstatus Universitas dan Institut dilengkapi gelar SH untuk alumni Fakultas Syariah menunjukkan bahwa pembumian semangat integrasi intelektual dan institusional semakin eskalatif.

Integrasi intelektual dapat dimaknai sebagai integrasi ontologis, epistemologis, dan aksiologis antara keilmuan syariah dan keilmuan hukum konvensional yang semakin hari semakin intensif. Integrasi intelektual berpotensi dan bisa menjadi solusi untuk menghilangkan dikotomi keilmuan (ilmu keislaman dan ilmu umum) yang saat ini telah tertanam kuat dalam memori sosial politik yuridis edukatif bangsa Indonesia. Sedangkan integrasi institusional bisa diartikan sebagai integrasi kultural dan struktural baik antara Fakultas Syariah dan Fakultas Hukum maupun antara pemangku kepentingan (stakeholders) sebagai pengguna alumni dan Fakultas Syariah sebagai produsen alumni. Integrasi institusional dimaksudkan untuk menghilangkan sekat-sekat institusional dan menghilangkan peluang diskriminasi oleh stakeholders kepada alumni Fakultas Syariah. Semangat dan upaya ini juga seiring dengan penghilangan sekat-sekat ekonomi dan politik di era Masyarakat Ekonomi Asean (MEA). Sehingga, pemberlakuan gelar SH diorientasikan agar alumni Fakultas Syariah bisa mengkontribusikan diri di semua lini dan profesi hukum.

26 Mahfud, Membangun Politik Hukum ..., h. 15 


\section{Politik Pemberlakuan Hukum}

Politik pemberlakuan hukum (enactment policy) adalah cara melaksanakan hukum dalam rangka mencapai tujuan bangsa dan negara. ${ }^{27}$ Politik pemberlakuan hukum menjadikan penerapan peraturan perundang-undangan sebagai objek politik, mencakup bagaimana suatu peraturan perundang-undangan bisa dilaksanakan dengan lancar tanpa ada protes dan penolakan dari masyarakat. Sejak diberlakukan pada tanggal 9 Agustus 2016 sampai tulisan ini diterbitkan Desember 2016, identifikasi dan analisis terhadap pemberlakuan gelar SH untuk alumni Jurusan HBS (Muamalah) Fakultas Syariah dilakukan dengan mencermati implikasi dan responsi terhadap gelar $\mathrm{SH}$ oleh stakeholders di bidang hukum dan berbagai fenomea terkait baik sebelum maupun sesudah pemberlakuan gear SH.Setiap muncul gelar baru tentu menggambarkan situasi sosial, ekonomi, politik, dan yuridis di Indonesia ketika gelar tersebut diberlakukan.

Pertama, situasi sosial-ekonomi, yakni adanya dinamika kehidupan sosialekonomi di masyarakat yang membutuhkan lebih banyak partisipasi sosial sarjana alumni Fakultas Syariah. Semakin berkembangnya ekonomi syariah di berbagai sektor, baik keuangan, investasi, eksplorasi, maupun bisnis lainya selalu diiringi berkembangnya problem masyarakat. Dalam situasi yag demikian, diperlukan sarjana yang bukan hanya memahami ekonomi syariah tetapi juga mehamai hukum Islam dan hukum konvensional.

Kedua, situasi sosial-politik, yakni adanya dinamika masyarakat di sektor politik yang ditandai dengan semakin terbukanya sistem rekrutmen dan promosi politik bagi siapa saja yang memiliki kemampuan dan kemauan di bidang ini untuk memasuki institusi politik strategis yang ada di Indonesia. Dengan fungsi legeslasi, budgeting, dan pengawasan yang dimiliki menjadikan institusi politik di Indonesia baik DPR RI maupun DPRD memiliki peran strategis untuk merumuskan peraturangan perundang-undangan sebagai cara membangun dan menjaga kemaslahatan masyarakat.

Ketiga, situasi sosial yuridis, yakni bertambahnya kewenangan Peradilan Agama untuk menyelesaikan sengketa ekonomi syariah. Berbagai problem hukum semakin banyak, begitu juga institusi dan forum penyelesaian sengketa di luar pengadilan juga semakin banyak, seperti mediasi, arbitase, adjudikasi, negosiasi, dan rekonsiliasi. Banyaknya praktisi hukum yang terjerat hukum akibat minimnya integritas moral mengharuskan tampilnya sarjana syariah bergelar $\mathrm{SH}$ yang memiliki integritas moral tinggi untuk mempersiapkan diri menjadi aktor-aktor strategis 27 Mahfud, Membangun Politik Hukum..., h. 15 
di sektor hukum baik sebagaikonsultan hukum, hakim, jaksa, panitera, juru sita, notaris, mediator, arbiter, maupun pengacara.

Setidaknya ada tiga harapan yang dimiliki alumni Fakultas Syariah dengan gelar SH. Pertama, sarjana alumni Jurusan HBS (Muamalah) Fakultas Syariah bukan saja dianggap memiliki kemampuan ilmu-ilmu kesyariahan, tetapi juga memiliki kemampuan ilmu hukum konvensional. Kedua, sarjana alumni Jurusan HBS (Muamalah) Fakultas Syariah bisa memasuki pasar kerja yang selama ini hanya bisa dimasuki oleh alumni Fakultas Hukum, seperti peradilan umum, kejaksaan, dan notaris.Ketiga, sarjana alumni Jurusan HBS (Muamalah) Fakultas Syariah bisa berinteraksi, berintegrasi, dan berkompetisi dengan sarjana alumni Fakultas Hukum bukan saja pada tataran ontologis dan epistemologis, tetapi juga pada tataran aksiologis.

\section{Gelar Akademik Sarjana Hukum dan Peluang Profesi di Sektor Hukum}

Ada empat profesi hukum formal yang diharapkan dan diidealkan bisa menyerap alumni Jurusan HBS (Muamalah) Fakultas Syariah, yaitu jaksa, hakim, notaris, dan advokat. Keempat profesi hukum tersebut masing-masing memiliki karakteristik, spesifikasi, dan urgensi yang diatur dalam peraturan perundangundangan.

1. Peluang menjadi jaksa

Sejauh ini jalan menuju profesi jaksa bagi alumni Jurusan HBS (Muamalah) Fakultas Syariah belum mulus. Hal ini tidak lepas dari salah satu syarat menjadi jaksa adalah berijazah paling rendah sarjana hukum. ${ }^{28}$ Di dalam UU Kejaksaan tidak ada penjelasan detail tentang cakupan ilmu hukum yang dimaksud. Menurut Jaksa Agung periode 2009-2014 Basrief Arief, sarjana lulusan Fakultas Syariah (Sarjana Syariah atau Sarjana Hukum Islam) dapat berpeluang menjadi tenaga advokat. Tetapi, untuk menjadi jaksa, Sarjana Hukum Islam atau Sarjana Syariah harus dibekali ilmu hukum umum. Sampai saat ini, sesuai UU Kejaksaan, persyaratan seorang calon jaksa masih mensyaratkan paling rendah berpendidikan sarjana hukum. Apabila eksistensi Sarjana Syariah ingin disejajarkan dengan Sarjana Hukum umum, harus dibekali ilmu hukum umum. Dengan demikian, sarjana syariah nantinya mempunyai nilai tambah. Selain memahami hukum umum juga memahami hukum Islam. ${ }^{29}$ Dengan demikian, hingga saaat ini UU

28 Pasal 9 ayat (1) UU No 16 Th 2004 Tentang Kejaksaan Republik Indonesia. Lihat juga, Peraturan Jaksa Agung(Perja) Republik Indonesia Nomor: Per-064/A/Ja/07/2007 tentang Rekrutmen Calon Pegawai Negeri Sipil dan Calon Jaksa Kejaksaan Republik Indonesia.

29 Bolehkah Sarjana Hukum Islam (S.H.I.) Mencalonkan Diri Menjadi Jaksa? diri-menjadi-jaksa. Diakses 25 November 2016 
Kejaksaan mensyaratkan seorang calon jaksa berpendidikan paling rendah sarjana hukumdalam konteks ilmu hukum umum, bukan ilmu hukum Islam. Seseorang yang berpendidikan sarjana hukum Islam yang ingin menjadi calon jaksa harus dibekali ilmu hukum umum. ${ }^{30}$

Menurut hemat penulis, pandangan Basrief Arief dilatarbelakangi oleh ketidaktahuannya terhadap kurikulum Jurusan HBS (Muamalah) Fakultas Syariah yang berlaku saat ini. Kurikulum Jurusan HBS (Muamalah) Fakultas Syariah saat ini semakin banyak mengakomodasi mata kuliah hukum konvensional yang dibutuhkan oleh steakholders dan mengikuti trend perkembangan pasar nasional dan internasional. Seandainya Basrief mengetahui seutuhnya kurikulum Jurusan HBS (Muamalah) Fakultas Syariah, maka pandangannya tentang kualitas alumni Jurusan HBS akan lebih akurat.

2. Peluang menjadi hakim dan panitera peradilan umum

Syarat kesarjanaan menjadi hakim dan panitera pada peradilan umum adalah sarjana hukum. Hal ini tertuang dalam pada pasal 14 ayat (1) poin (f) dan pasal 29 poin (b) UU Nomor 2 Tahun 1986 tentang Peradilan Umum yang telah disempurnakan dengan UU Nomor 49 Tahun 2009 tentang Kekuasaan Kehakiman. ${ }^{31}$ Apakah sarjana hukum Islam termasuk di dalam bagian sarjana hukum? Di dalam UU tersebut tidak ada penjelasan cakupan sarjana hukum. Tidak adanya penjelasan kemencakupan sarjana hukum ini tampaknya dipahami oleh Mahkamah Agung bahwa makna sarjana hukum dalam Pasal 14 dan 29 tersebut adalah alumni S1 Fakultas Hukum bukan alumni S1 Jurusan HBS (Muamalah) Fakultas Syariah.

Ketika melakukan rekrutmen Panitera tahun 2016 Mahkamah Agung mempersyaratkan calon panitera peradilan umum harus alumni S1 Fakultas hukum. Sedangkan calon panitera peradilan agama boleh S1 Fakultas Hukum atau S1 Fakultas Syariah. ${ }^{32}$ Hal ini menunjukkan bahwa dalam pandangan pemegang kebijakan di Mahkamah Agung, alumni S1 Jurusan HBS (Muamalah) Fakultas Syariah hanya bisa menjadi hakim dan panitera Peradilan Agama. Sedangkan S1 Fakultas hukum bisa menjadi hakim dan panitera di seluruh peradilan. Kondisi

30 Bolehkah Sarjana Hukum Islam (S.H.I.) Mencalonkan Diri Menjadi Jaksa? diri-menjadi-jaksa. Diakses 25 November 2016

31 Pasal 14 ayat (1) poin (f) dan pasal 29 poin (b) UU Nomor 2 Tahun 1986 tentang Peradilan Umum yang telah disempurnakan dengan UU Nomor 49 Tahun 2009 tentang Kekuasaan Kehakiman

32 Lowongan CPNS MA-Mahkamah Agung, http://www.pusatinfocpns.com/lowongan-cpnsma-mahkamah-agung/, diakses 27 November 2016 
ini tidak lepas dari sejarah panjang tarik ulur kewenangan antara hukum Islam dan sarjana hukum Islam di satu pihak dengan hukum adat/hukum Barat dan sarjana hukum umum di pihak lain, sehingga memunculkan teori credo, teori receprie in complexu, teori receptie, teori receptie exit, teori receptio a contrario, teori existence, dan teori authority of law, dan teori obligation.

3. Peluang menjadi notaris

Menurut Pasal 3 poin (e) UU Nomor 30 Tahun 2004 Tentang Jabatan Notaris yang telah disempurnakan dengan UU Nomor 2 Tahun 2014 Tentang Perubahan Atas Undang-Undang Nomor 30 Tahun 2004 Tentang Jabatan Notaris, bahwa syarat untuk dapat diangkat menjadi notaris hatus berijazah sarjana hukum dan lulusan jenjang strata dua kenotariatan. ${ }^{33}$ Apakah sarjana hukum Islam termasuk di dalam pengertian sarjana hukum?Jika kata "sarjana hukum" ditafsirkan secara ekstensif (perluasan makna), maka Sarjana Hukum Islam merupakan bagian dari kata "sarjana hukum". Namun, jika ditafsirkan secara restriktif (penyempitan makna), maka sarjana hukum Islam bukan bagian dari sarjana hukum.

Di dalam UU Nomor 30 Tahun 2004 Tentang Jabatan Notaris yang telah disempurnakan dengan UU Nomor UU Nomor 2 Tahun 2014 Tentang Perubahan Atas Undang-Undang Nomor 30 Tahun 2004 Tentang Jabatan Notaris tidak ada penjelasan tentang sarjana hukum. Tidak adanya penjelasan tentang "sarjana hukum" di dalam UU tersebut dimaknai oleh Asosiasi Pengelola Magister Kenotariatan (MKn) se-Indonesia, bahwa hanya alumni S1 alumni Fakultas Hukum yang bisa melanjutkan studi ke jenjang Magister Kenotariatan. Hal ini tergambar dari pernyataan Rahmat Budiono, Ketua program Studi Magister Kenotariatan (MKn) Fakultas Hukum Universitas Brawijaya Malang pada 2013. Menurut Rahmat Budiono, ada kesepakatan di Asosiasi Pengelola MKn bahwa hanya S1 Fakultas Hukum yang boleh melanjutkan studi ke jenjang magister kenotariatan. ${ }^{34}$ Pernyataan Rahmat Budiono ini semakin terbukti ketika Danar Rizki Fauzi, SHI, staf legal officer BTN Syariah Cabang Malang dan alumni Jurusan HBS Fakultas Syariah UIN Maulana Malik Ibrahim Malang ditolak daftar di MKn Fakultas Hukum Universitas

33 Pasal 3 poin (e) UU Nomor 30 Tahun 2004 Tentang Jabatan Notaris yang telah disempurnakan dengan UU Nomor 2 Tahun 2014 Tentang Perubahan Atas Undang-Undang Nomor 30 Tahun 2004 Tentang Jabatan Notaris

34 Catatan Wawancara, Dr. Rahmat Budiono, SH, MH., 2013.Penulis bersama Dr. H. Dahlan Tamrin, M.Ag (ketika itu Ketua Pagram Studi S2 Al-Akhwal al-Syakhsiyyah) bersilaturahmi ke Dr. Rahmat Budiono, SH., MH selaku Ketua Program Magister Kenotariatan (MKn) Fakultas Hukum Universitas Brawijaya dan mendiskusikan kemungkinan dibukanya S2 Notariat Syariah di UIN Maulana Malik Ibrahim Malang. 
Brawijaya dengan alasan bukan alumni Fakultas Hukum. ${ }^{35}$ Namun, pada tahun 2015 ada alumni Jurusan HBS Fakultas Syariah UIN Malang bernama Naghfir, SHI diterima menjadi mahasiswa Program MKn Fakultas Hukum Universitas Brawijaya Malang. Hal ini menunjukkan bahwa ada perubahan kebijakan di Program Magister Kenotariatan (MKn) Fakultas Hukum Universitas Brawijaya Malang. Pada awalnya melarang, namun akhirnya menerima alumni Jurusan HBS Fakultas Syariah menjadi mahasiswa Program Magister Kenotariatan (MKn).

Fenomena positif yang berlaku di Program MKn Fakultas Hukum Universitas Brawijaya ternyata berbeda dengan kebijakan yang berlaku di Program MKn Fakultas Hukum Universitas Airlangga. Pada tahun 2016, ada alumni Jurusan Hukum Bisnis Syariah Fakultas Syariah UIN Malang bernama Silvia Mufarokhah, SH yang tidak lolos berkas mengikuti seleksi pada Program MKn Fakultas Hukum Universitas Airlangga dengan alasan bukan lulusan dari Fakultas Hukum. Kondisi ini menunjukkan bahwa ada perbedaan kebijakan setiap pengelola MKn antara Perguruan Tinggi yang satu dan yang lain. Begitu juga, kondisi ini menggambarkan masih ada perlakuan berbeda dan menjadi jalan terjal bagi alumni Fakultas Syariah untuk melanjutkan S2 MKn sebagai syarat menjadi notaris.

4. Peluang menjadi advokat

Menurut Pasal 2 ayat (1) UU Nomor 18 Tahun 2003 Tentang Advokat, bahwa yang dapat diangkat sebagai advokat adalah sarjana yang berlatar belakang pendidikan tinggi hukum dan setelah mengikuti pendidikan khusus profesi Advokat yang dilaksanakan oleh Organisasi Advokat. ${ }^{36}$ Makna kata "sarjana yang berlatar belakang pendidikan tinggi hukum" bisa dicermati pada penjelasan UU Pasal 2 ayat (1) UU Nomor 18 Tahun 2003 Tentang Advokat. Di dalam penjelasan tersebut dinyatakan, bahwa yang dimaksud dengan "berlatar belakang pendidikan tinggi hukum" adalah lulusan fakultas hukum, fakultas syariah, perguruan tinggi hukum militer, dan perguruan tinggi ilmu kepolisian.

Terkait dengan peluang sarjana alumni Fakultas Syarah, tampak jelas bahwa UU Advokat sangat berbeda dengan UU Kejaksaan, UU Kehakiman, dan UU Jabatan Notaris. UU Advokat dengan tegas menyebut dan menjelaskan bahwa alumni Fakultas Syariah bisa menjadi advokat. Sedangkan UU Kejaksaan, UU Kehakiman, dan UU Jabatan Notaris cenderung melarang alumni Fakultas syariah dan hanya memberi kesempatan kepada sarjana alumni Fakultas Hukum untuk menjadi jaksa, hakim

35 Catatan Wawancara, Danar Rizki Fauzi, 2016.

36 Pasal 2 ayat (1) UU Nomor 18 Tahun 2003 Tentang Advokat 
peradilan umum, dan notaris. Politk hukum nasional yang belum berpihak kepada alumni Fakultas Syariah inilah yang tampaknya melatarbelakangi Forum Dekan Fakultas Syariah se Indonesia mengusulkan kepada Direktur Pendidikan Tinggi Islam Direktorat Jenderal Pendidikan Islam Kementerian Agama Republik Indonesia untuk merubah gelar alumni Fakutas Syariah dari Sarjana Hukum Islam (SHI)/Sarjana Syariah (S.Sy) menjadi Sarjana Hukum (SH).

\section{Tantangan Gelar Sarjana Hukum di Era Masyarakat Ekonomi ASEAN}

Momentum perubahan gelar dari SHI/S.Sy menjadi SH seiring dengan pemberlakuan zona Masyarakat Ekonomi Asean (MEA). Kompetisi antara warga ASEAN dalam berbagai bidang tidak terelakkan. Setiap warga ASEAN dituntut untuk responsif terhadap tanda-tanda zaman yang terus berubah cepat. Sarjana alumni Fakultas Syariah sebagai bagian penting dari warga ASEAN harus terus melengkapi diri dengan modal sosial, ekonomi, pendidikan, dan hukum untuk bisa bersaing di kancah MEA. Oleh karena itu, upaya dan langkah strategis untuk memperkuat mutu lulusan Jurusan HBS (Muamalah) Fakultas Syariah harus terus dilakukan oleh yang bersangkutan sebagai pemegang gelar akademik maupunoleh Fakultas Syariah secara konsisten dan berkesinambungan. Langkah strategis bisa dirumuskan secara valid, visioner, dan kontekstual jika didahului oleh diagnosa yang akurat atas berbagai tantangan dan problem yang selama ini mengitari sarjana alumni Jurusan HBS (Muamalah) Fakultas Syariah baik yang melanjutkan studi ke strata dua (S2) maupun yang berkarir di pasar kerja berbasis hukum.

Ada beberapa kasus yang menjadi tantangan alumni Jurusan HBS (Muamalah) Fakultas Syariah pemegang gelar SH. Pertama, belum semua pemangku kepentingan (stakeholders) mengetahui perubahan gelar dari SHI/S.Sy menjadi SH. Ketidaktahuan ini menyebabkan banyak stakeholders tetap membedakan antara SH alumni Jurusan HBS (Muamalah) Fakultas Syariah dan SH alumni Fakultas Hukum. Sebagai contoh, akhir 2016 ada rekrutmen Panitera oleh Mahkamah Agung. Di pengumuman Nomor 1 tertulis "dibutuhkan 100 panitera peradilan umum". Kualifikasi pendaftar yang dibutuhkan adalah "S1 Fakultas Hukum". Pada nomor urut 2 tertulis "dibutuhkan 100 panitera peradilan agama". Kualifikasi pendaftar yag dibutuhkan adalah "S1 Fakultas Syariah atau S1 Fakultas Hukum". Berdasarkan pengumuman rekrutmen tersebut tampak jelas bahwa Mahkamah Agung membedakan SH alumni Jurusan HBS (Muamalah) Fakultas Syariah dan SH alumni Fakultas Hukum. 
Kedua, belum semua pengelola S2 ilmu hukum dan S2 kenotariatan mengetahui dan mengerti perubahan gelar dari SHI/SSy menjadi SH. Ketidakpahaman dan ketidakmengertian ini menyebabkan beberapa pengelola S2 ilmu hukum dan kenotariatan tidak mau menerima alumni Jurusan HBS (Muamalah) Fakultas Syariah sebagai mahasiswa S2 ilmu hukum. Sebagai contoh adalah pengalaman Silvia Mufarokhah, alumni Jurusan Hukum Bisnis Syariah (HBS) Fakultas Syariah UIN Maulana Malik Ibrahim Malang. Silvia ikut wisuda bulan Oktober 2016 dan menyandang gelar SH. Ketika mendaftar secara on line S2 ilmu hukum Fakulas Hukum (FH) Universitas Airlangga (Unair) Surabaya semua persyaratan lengkap kecuali ijazah. Karena ijazah belum keluar, diganti surat keterangan lulus (SKL) ${ }^{37}$ Beberapa hari kemudian muncul jawaban secara on line dari pengelola S2 Ilmu Hukum FH Unair sebagai berikut:

"Mohon maaf, karena pada Surat Keterangan Lulus tidak menyebutkan gelar dan setelah dilihat dari transkrip Saudara, Magister Ilmu Hukum hanya menerima lulusan prodi ilmu hukum bukan yang lain. Disarankan mendaftar di Prodi lain".38

Menanggapi jawaban pengelola Magister ilmu hukum FH Unair, Silvia kemudian melengkapi SKL baru dengan mencantumkan gelarnya. Tetapi tetap tidak lolos verifikasi berkas dengan alasan yang sama, yakni bukan alumni Fakultas Hukum. Kemudian Silvia mengambil S2 kenotariatan di FH Unair, tetap tidak lolos. Setelah dikonfirmasi langsung ke FH Unair, diperoleh jawaban lisan bahwa program S2 ilmu hukum Unair dan program S2 kenotariatan FH Unair tidak menerima pendaftar selain dari alumni $S 1$ lmu hukum murni. ${ }^{39}$

Penolakan oleh pengelola S2 ilmu hukum FH Unair ini berbeda dengan pengelola S2 ilmu hukum Fakultas Hukum Universitas Brawijaya, Universitas Diponegoro, Universitas Gajah Mada, dan Universitas Indonesia. Di empat kampus tersebut alumni Fakultas Syariah diterima dengan tangan terbuka. Pertama, Universitas Brawijaya.Sampai November 2016 tercatat ada empat alumni Jurusan HBS Fakultas Syariah UIN Malang yang telah selesai studi S2 ilmu Hukum FH Universitas Brawijaya, yaitu Dwi Fidayanti, SHI, MH (kini dosen tetap non-PNS Fakultas Syariah UIN Malang), Erry Fitria, SHI, MH (kini dosen tetap non-PNS Fakultas Syariah IAIN Palangkaraya), Zakiah Asfia, SHI, MH (kini tinggal di Banjarmasin), dan Dimas Yulia, SHI, MH (kini tinggal di Lamongan). Selain yang

37 Catatan Wawancara, Silvia Mufarokhah, pemegang gelar SH dari Jurusan Hukum Bisnis Syariah Fakultas Syariah UIN Maulana Malik Ibrahim Malang, wisuda pada bulan Oktober 2016

38 Pengumuman hasil verifikasi berkas pendaftaran mahasiswa S2 ilmu Hukum Fakultas Hukum Universitas Airlangga Surabaya, 2016

39 Catatan Wawancara, Silvia Mufarokhah, 2016 
sudah selesai S2, masih banyak juga alumni Jurusan HBS dan Jurusan al-Ahwal al-Syakhsiyyah (AS) yang sedang studi S2 di ilmu hukum di FH UB.

Kedua, Universitas Diponegoro. Tahun 2016 ini ada satu alumni jurusan HBS yang diterima S2 ilmu hukum Fakultas Hukum Universitas Diponegoro, yaitu Ahmad Dzikrulloh, wisuda bulan Oktober 2016 dan pemegang gelar SH. Ketiga, Universitas Gadjah Mada, yakni Tahun 2015 ada satu alumni Jurusan HBS yang diterima S2 ilmu hukum FH Universitas Gajah Mada, yaitu Walida Latifatuz Zahroh, SHI. Sedangkan pada 2016 ada satu alumni HBS yang diterima S2 ilmu hukum di UGM yaitu Ariza Ekky Saputri, SHI (penerima beasiswa LPDP).Keempat,Universitas Indonesia. Tahun 2016 ini ada satu alumni Jurusan HBS Fakultas Syariah UIN Maulana Malik Ibrahim Malang yang diterima S2 ilmu hukum Fakultas Hukum Universitas Indonesia, yaitu Choirul Lutfi, SHI (penerima bea siswa LPDP).

Mengacu pada uraian di atas dapat dijelaskan bahwa tantangan alumni Fakultas Syariah bukan hanya berkompetisi dengan sarjana dari luar Indonesia, tetapi juga berkompetisi dengan sesama sarjana hukum Indonesia. Kompetisi ini akan semakin seru karena sarjana alumni Jurusan HBS (Muamalah) Fakultas Syariah harus pula menghadapi miss-understanding sejumlah pengelola S2 ilmu hukum dan potensi munculnya perlakuan diskriminatif oleh stakeholders yang belum welcome terhadap alumni Jurusan HBS (Muamalah) Fakultas Syariah. Miss-understanding dan perilaku diskriminatif potensial menghasilkan sumber daya manusia di sektor hukum yang bermental diskriminatif pula dan jauh dari adil dan berwibawa.

Suatu peraturan yang belum sempurna, namun jika aparat hukumnya adil dan berwibawa, maka kelemahan suatu peraturan bisa disempurnakan oleh keadilan dan kewibawaan aparat hukum.40 Urgensi pengakomodasian alumni Jurusan HBS (Muamalah) Fakultas Syariah ke sektor hukum terletak pada penyiapan sumber daya manusia sebagai penegak hukum. Sehingga, berbagai kasus kriminal yang selama ini dilakukan oleh oknum aparat hukum bisa dihilangkan. Penegak hukum yang adil dan berwibawa akan muncul di tengah proses rekrutmen dan kompetisi yang adil dan berwibawa pula.

40 Mohamad Nur Yasin, "Perbandingan Green Konstitusi, Green Ekonomi, dan Hukum Ekonomi Syariah di Indonesia, Asy-Syir'ah, Jurnal Ilmu Syari’ah dan Hukum, Vol 50, No. 1, Juni 2016/1437, h. 133 


\section{Simpulan}

Berdasarkan uraian di atas ada beberapa kesimpulan penting yang bisa dikemukakan, yaitu: Pertama, Politik hukum pemberlakuan gelar Sarjana Hukum (SH) untuk alumni Jurusan HBS (Muamalah) Fakultas Syariah mencakup politik perumusan hukum, substansi hukum, dan pemberlakuan hukum. Pertama, politik perumusan hukum untuk mewujudkan gelar SH bagi alumni Fakultas Syariah berlangsung lama dan melelahkan. Perumusan dilakukan secara top down oleh pemegang kebijakan di tingkat pusat dan secara buttom up oleh para praktisi serta Dekan Fakultas Syariah se-Indonesia. Integrasi dan interkoneksi antara pendekatan top down dan buttom up menghasilkan rumusan final perlunya gelar SH untuk alumni Fakultas Syariah yang tertuang dalam PMA Nomor 33 tahun 2016 tentang Tentang Gelar Akademik Perguruan Tinggi Keagamaan. Kedua, politik substansi hukum pemberlakuan gelar SH untuk alumni Jurusan HBS (Muamalah) Fakultas Syariah adalah empowering dan implementasi semangat integrasi dan interkoneksi keilmuan serta dalam rangka mendistorsi dikotomi kelembagaan. Ketiga, politik pemberlakuan hukum (enactment policy) menunjukkan masih adanya sejumlah pengelola S2 ilmu hukum dan S2 kenotariatan serta stakeholders yang belum memahami esensi gelar SH untuk alumni Jurusan HEBS (Muamalah) Fakultas Syariah, sehingga masih muncul bentuk-bentuk perlakuan diskriminatifdan kontra-justisia. Sebagai respon atas berbagai miss-undertanding tersebut tampak sejumlah Fakultas Syariah terus melakukan dan menjaga mutu keilmuan alumninya sekaligus sosialisasi ke berbagai stakeholders terkait. Kedua, Jika para pengelola S2 ilmu hukum dan S2 kenotariatan serta stakeholders hukum meliputi Kejaksaan Agung, Mahkamah Agung, dan Asosiasi Notaris Indonesia mengetahui adanya kualitas keilmuan syariah dan kualitas keilmuan hukum konvensional pada diri alumni Fakultas Syariah dan memberi kesempatan kepada alumni tersebut untuk berkarir di dunia hukum, maka pergantian gelar dari SHI/S.Sy menjadi SH bisa secara total menyelesaikan problem yuridis yang selama ini dibebankan kepada alumni Jurusan HBS (Muamalah) Fakultas Syariah. Namun, jika sebaliknya, maka pergantian gelar dari SHI/S.Sy menjadi SH tidak otomatis memberikan side effect positif apapun kepada alumni Jurusan HBS (Muamalah) Fakultas Syariah. 


\section{Daftar Pustaka}

Buku

Amiruddin dan Zainal Asikin. Pengantar Metode Penelitian Hukum. Bandung: Citra Aditya Bakti, 2006.

Anderson, James Norman Darlymple. Islamic Law in the Modern Word. Virginia: Greenwood Publishing Group, 1975.

Mahfud, Moh. Membangun Politik Hukum, Menegakkan Konstitusi. Jakarta: Rajawali Press, 2012.

Mayer, Ann Elizabeth. “The Syariah: a Methodology or a Body of Substantive Rules”, in Nicholas Heer, Islamic Law and Jurisprudence. Seattle and London: University of Washington Press, 1990.

Muslehuddin, Muhammad. Filsafat Hukum Islam dan Pemikiran Orientalis, Studi Perbandingan Sistem Hukum Islam. Terjemahan oleh Yudian W. Asmin. Yogyakarta: Tiara Wacana Yogya, 1991.

Rahardjo, Satjipto. Ilmu Hukum. Bandung: Citra Aditya Bhakti, 1991

Robertson, Roland (ed). Agama dalam Analisa dan Interpretasi Saosiologis. Jakarta: Rajawali Press, 1988.

Artikel

Yasin, Mohamad Nur. "Perbandingan Green Konstitusi, Green Ekonomi, dan Hukum Ekonomi Syariah di Indonesia”, Asy-Syir'ah, Jurnal Ilmu Syariah dan Hukum, Vol 50, Nomor 1: Juni 2016/1437.

Yasin, Mohamad Nur. "The Pluralism of Islamic Economic Law, Dialectic of Moslem and non-Moslem in the Development of Sharia Banking in Indonesia", Journal of Indonesian Islam, Vol. 10, Number 01: June 2016.

\section{Peraturan Perundang-undangan}

Undang-Undang Dasar Republik Indonesia 1945

Undang-Undang Republik Indonesia Nomor.20 Tahun 2003 TentangSistem Pendidikan Nasional (Lembaran Negara Republik Indonesia Tahun 2003 Nomor 78, Tambahan Lembaran Negara Republik Indonesia Nomor 4301)

Undang-Undang Republik Indonesia Nomor 16 Tahun 2004 Tentang Kejaksaan Republik Indonesia (Lembaran Negara Republik Indonesia Tahun 2004 Nomor 
67, Tambahan Lembaran Negara Republik Indonesia Nomor 4401)

Undang-Undang Republik Indonesia Nomor 8 Tahun 2003 Tentang Advokat (Lembaran Negara Tahun 2003 Nomor 49, Tambahan Lembaran Negara Republik Indonesia Nomor 4288)

Undang-Undang Republik Indonesia Nomor 2 Tahun 1986 Tentang Peradilan Umum (Lembaran Negara Tahun 1986 Nomor 20, Tambahan Lembaran Negara Republik Indonesia Nomor 3327)

Undang-Undang Republik Indonesia Nomor 2 Tahun 2014 Tentang Perubahan Atas UU No. 30 Th 2004 Tentang Jabatan Notaris (Lembaran Negara Republik Indonesia Tahun 2014 Nomor 3, Tambahan Lembaran Negara Republik Indonesia Nomor 5491

Undang-Undang Republik Indonesia Nomor 30 Tahun 2004 Tentang Jabatan Notaris (Lembaran Negara Republik Indonesia Tahun 2004 Nomor 117, Tambahan Lembaran Negara Republik Indonesia Nomor 4432)

Undang-Undang Republik Indonesia Nomot 48 Tahun 2009 Tentang Kekuasaan Kehakiman (Lembaran Negara Tahun 2009 Nomor 157, Tambahan Lembaran Negara Republik Indonesia Nomor 5076)

PeraturanJaksa AgungRepublikIndonesia Nomor:Per-064/A/Ja/07/2007tentangRekrutmen Calon Pegawai Negeri Sipil dan Calon Jaksa Kejaksaan Republik Indonesia.

Peraturan Menteri Agama Nomor 33 Tahun 2016 Tentang Tentang Gelar Akademik Peguruan Tinggi Keagamaan

Peraturan Menteri Agama Nomor 36 Tahun 2009 Tentang Penetapan Pembidangan Ilmu dan Gelar Akademik di Lingkungan Peguruan Tinggi Agama

Peraturan Menteri Agama Nomor 33 Tahun 2016 Tentang Tentang Gelar Akademik Peguruan Tinggi Keagamaan

Keputusan Direktur Jenderal Kelembagaan Agama Islam Departemen Agama Republik Indonesia Nomor: E/10/ Tahun 2002 Tentang Gelar dan Sebutan Lulusan Perguruan Tinggi Agama Islam.

Keputusan Menteri Pendidikan dan Kebudayaan Republik Indonesia Nomor 036/ U/1993 Tentang Gelar dan Sebutan Lulusan Perguruan Tinggi 